\title{
LIETUVOS JAUNIMO RINKTINĖS ŽAIDE்JŲ FIZINIS IŠSIVYSTYMAS, JO YPATUMAI IR KAITA
}

\author{
Rūtenis Paulauskas \\ Vilniaus pedagoginis universitetas, Vilnius, Lietuva
}

\begin{abstract}
Rūtenis Paulauskas. Biomedicinos mokslų daktaras. Vilniaus pedagoginio universiteto Sporto metodikos katedros docentas. Mokslinių tyrimų
\end{abstract} kryptis - jaunujų krepšininkų rengimas ir jų organizmo adaptacija prie fizinių krūvių.

\section{SANTRAUKA}

Didejanti konkurencija tarp žaidèju, ypač tarp jaunu, skatina trenerius domètis ne tik taktiniu, techniniu rengimu, bet ir sportininku fizinio vystymosi raida, adaptacijos prie fiziniu krūviu ypatumais. Daugelis autoriu yra ištyrę, kad nors jaunieji sportininkai savo fizine branda dar atsilieka nuo suaugusiuju, tačiau kai kuriu organizmo funkcinès galimybès siekia didelio meistriškumo sportininku lygị. Žaidžiant krepšini, sportinį rezultata dažnai lemia fizinès ypatybès, tačiau ūgio, kūno ir raumenu masès rodikliai taip pat labai svarbūs. Tyrimu norèta išsiaiškinti, kaip reguliariai krepšini žaidžiančiu jaunuoliu fizinio išsivystymo rodikliai kinta per ketverius metus.

Tyrimo tikslas - ištirti geriausiu 16-19 m. Lietuvos krepšininku — kandidatu i šalies rinktinę - fizinio išsivystymo kaitos rodiklius ir palyginti juos su to paties amžiaus nesportuojančiuju.

Tirti jaunieji krepšininkai $(n=14)$, atstovavę ¿vairaus amžiaus Lietuvos rinktinèms. Žaidejjus tyrème ketverius metus iš eilès — nuo 16 iki 19 metu amžiaus. Tyrimai atlikti kiekvienu metu vasarq rengiantis Europos ir pasaulio čempionatams. Tyrimo metu nustatème: 1) ūgi, ūgi sèdint, siekimo stovint rezultatus; 2) kūno masę, küno masès indeksq (KMI); 3) plaštaku statinès jëgos rodiklius; 4) gyvybini plaučiu tūrì (GPT); 5) riebalu ir raumenu masę, ju indeksa (RRMI).

Tyrimo rezultatai apdoroti matematinès statistikos metodais.

Nustatyta, kad Lietuvos ìvairaus amžiaus krepšinio rinktinès žaidëju ūgis yra kur kas didesnis už nesportuojančiuju. Taigi atranka ì šiq sporto šaka yra specifine. Tirtujaunuju krepšininku kūno masè vidutiniškai $10 \mathrm{~kg}$ didesnè už nesportuojančiuju, tačiau augimo tempai panašūs.

Atlikti tyrimai leidžia manyti, kad krepšini žaidžiančiu jaunuoliu plaštaku statinès jègos rodikliai yra nepakankami. Palyginus 16 ir 17 m. žaidejujejgos rodiklius su to paties amžiaus nesportuojančiuju matyti, kad vidutiniai krepšininku rodikliai blogesni.

Labiausiai raumenu masè ir statine jèga didèjo nuo 18 metu amžiaus. Manome, kad tam turëjo įtakos tiek fizinis krūvis, tiek augimo fiziologiniai dèsningumai.

Raktažodžiai: ̄gis, kūno masé, riebalu ir raumenu masè, statine jëga.

\section{IVADAS}

$\mathrm{J}$ aunujų krepšininkų rengimas Lietuvoje yra sistemingas ir organizuotas pedagoginis procesas. Daugelyje šalies miestų ir rajonų veikia specializuotos sporto mokyklos, vykdomos moksleivių varžybos, formuojamos įvairaus amžiaus nacionalinès rinktinès. Didèjanti konkurencija tarp žaideju, ypač tarp jaunų, skatina trenerius domètis ne tik taktiniu, techniniu rengimu, bet ir sportininkų fizinio vystymosi raida, adaptacijos prie fiziniu krūvių ypatumais.

Daugelis autoriu yra ištyrę, kad nors jaunieji sportininkai savo fizine branda dar atsilieka nuo suaugusiuju, tačiau kai kurių organizmo funkcinès galimybès siekia didelio meistriškumo sportininkų lygi (Lašienė ir kt., 1994; Katzmarzyk et al., 2003; Eisenmann et al., 2005). Sportas ir fizinis aktyvumas nelabai veikia somatinius ūgio ir kūno masės rodiklius (Janz et al., 2000; Paulauskas ir kt., 2005; Matton et al., 2007), tačiau kaip fizinio išsivystymo rodiklius veikia reguliarios krepšinio pratybos tyrinèta nepakankamai.

Žaidžiant krepšini, sportinị rezultatą dažnai lemia fizinès ypatybès, tačiau ūgio, kūno ir raumenų masès rodikliai taip pat labai svarbūs. Tyrimu 
norèta išsiaiškinti, kaip kinta reguliariai krepšini žaidžiančiu jaunuolių fizinio išsivystymo rodikliai per ketverius metus.

Tyrimo tikslas - ištirti geriausių $16-19 \mathrm{~m}$. Lietuvos krepšininku - kandidatų i šio amžiaus šalies rinktines - fizinio išsivystymo kaitos rodiklius ir palyginti juos su to paties amžiaus nesportuojančiuju.

Tiriamieji. Tirti 16-19 m. krepšininkai $(\mathrm{n}=14)$, atstovavę i̇vairaus amžiaus Lietuvos rinktinèms.

\section{TYRIMO ORGANIZAVIMAS IR METODAI}

Žaidèjus tyrème ketverius metus iš eilès - nuo 16 iki 19 metų amžiaus. Tyrimai vyko keturis kartus - kiekvienu metu vasarą rengiantis Europos ir pasaulio čempionatams. Jaunuju krepšininku fizinis išsivystymas tirtas naudojant antropometrijos metodą (Skernevičius ir kt., 2004). Nustatyta:

1. Ūgis, ūgis seddint, aukščiausio taško siekimo stovint rezultatai.

2. Kūno masè, kūno masės indeksas (KMI).

3. Plaštakų statinès jẻgos rodikliai.

4. Gyvybinis plaučių tūris (GPT).

5. Riebalu ir raumenų mase, jos indeksas (RRMI) (Juocevičius, Guobys, 1985).

Tyrimo rezultatai apdoroti matematinès statistikos metodais: apskaičiuotas aritmetinis vidurkis $(\overline{\mathrm{X}})$, standartinis nuokrypis (S). Pateiktas didžiausias ir mažiausias rodiklis. Apskaičiuotas aritmetinių vidurkių skirtumo patikimumas taikant dispersinès analizès $(A N O V A)$ metodą ir nustačius $F$ kriterijų. Atskiru požymių sąsaja įvertinta atliekant tiesinès koreliacijos (Pirsono) tyrimą.

\section{REZULTATAI}

Tirti specifinès grupès jaunuoliu — krepšininku - augimo tempai per ketverius metus. Lyginant $16 \mathrm{~m}$. krepšininkų $(\mathrm{n}=14)$ ūgi su to paties amžiaus nesportuojančiujų (Eurofitas, 2002), matyti didelis rodikliu skirtumas $\overline{\mathrm{x}}=12,1 \mathrm{~cm}(\mathrm{p}<0,05)$ (1 pav., 1, 2 lent.). Tyrimo laikotarpiu užfiksuota žaidèjų ūgio didèjimo tendencija. Didesni augimo tempai pastebèti per pirmuosius dvejus tyrimo metus. Ketvirto tyrimo metu vidutinis komandos tiriamujų ūgis siekè 197,29 \pm 7,03 cm.

JAV atlikti to paties amžiaus nesportuojančių jaunuoliu tyrimai parode (Malina, Bouchard, 1991), kad jų ūgis $\overline{\mathrm{x}}=15,5 \mathrm{~cm}$ mažesnis už tirtų Lietuvos jaunujų krepšininkų (1 pav.), tačiau nuo 16 iki 18 metų amžiaus augimo tempai yra tokie patys $-\overline{\mathrm{x}}=4 \mathrm{~cm}$. Kaip specifiškai svarbu krepšininkams fizinio išsivystymo rodikli tyrème galūnių ilgi, išmatuodami siekimo ranka aukšti ir ūgi sẻdint. Akivaizdu, kad galūnių ilgis leidžia žaidejjui būti pranašesniam prieš varžovą. Atsiranda galimybe sugauti ir mesti kamuoli iš aukščiau. Per dvejus metus (nuo 16 iki 17 m.) siekimo ranka vidutiniai rodikliai padidejo $6,91 \mathrm{~cm}(\mathrm{p}>0,45)$, ùgis sédint $-3,33 \mathrm{~cm}(\mathrm{p}<0,01)$.

Didejjant ūgiui, auga ir kūno masè, todèl tirtu Lietuvos jaunujų krepšininkų vidutiniai kūno masès

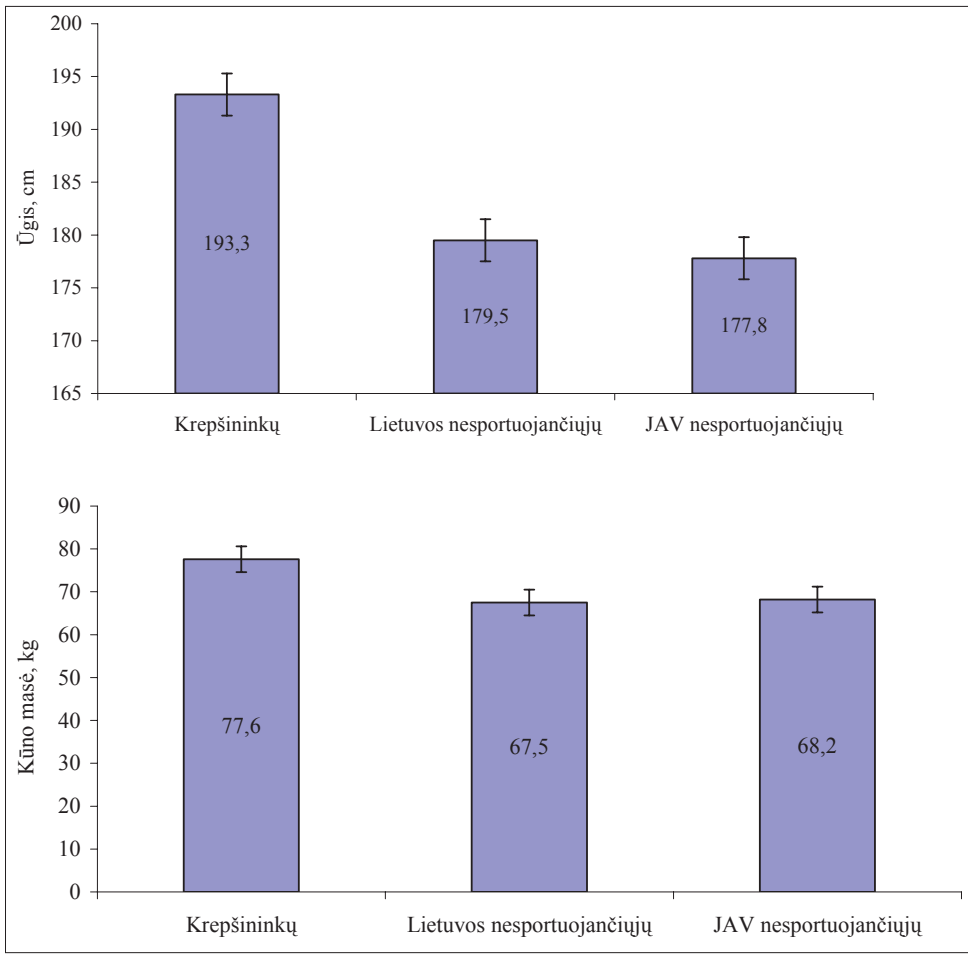

1 pav. Tirtų Lietuvos 16 m. krepšininkų, Lietuvos ir JAV nesportuojančiųjų vidutiniai ūgio ir kūno masès rodikliai 
1 lentelè. Tirtų 16-19 m. Lietuvos jaunųjų krepšininkų fizinio išsivystymo rodiklių kaita

\begin{tabular}{|c|c|c|c|c|c|c|c|c|c|c|c|c|}
\hline \multirow{2}{*}{$\begin{array}{l}\text { Ririamugjų Rodikliai } \\
\text { amžius }\end{array}$} & \multirow[b]{2}{*}{ Rod. } & \multirow{2}{*}{$\begin{array}{c}\overline{\text { Ügis, }} \\
\text { cm }\end{array}$} & \multirow{2}{*}{$\begin{array}{l}\text { Ūgis } \\
\text { sèdint, } \\
\text { cm }\end{array}$} & \multirow{2}{*}{$\begin{array}{c}\text { Siekimas } \\
\text { stovint, } \\
\text { cm } \\
\end{array}$} & \multirow{2}{*}{$\begin{array}{c}\text { Kūno } \\
\text { masé, } \\
\text { kg }\end{array}$} & \multirow{2}{*}{$\begin{array}{c}\mathrm{KMI} \\
\mathrm{kg} / \mathrm{m}^{2}\end{array}$} & \multicolumn{2}{|c|}{ Jèga, kg } & \multirow[b]{2}{*}{ GPT, I } & \multirow{2}{*}{$\begin{array}{c}\text { Rieb., } \\
\text { kg }\end{array}$} & \multirow{2}{*}{$\begin{array}{c}\text { Raum., } \\
\text { kg }\end{array}$} & \multirow[b]{2}{*}{ RRMI } \\
\hline & & & & & & & D & K & & & & \\
\hline \multirow{4}{*}{$\begin{array}{c}\mathrm{I} \\
16 \mathrm{~m} .\end{array}$} & $\overline{\mathrm{x}}$ & 193,33 & 98,92 & 249,92 & 77,58 & 20,85 & 42,33 & 37,50 & 5,30 & 7,66 & 41,27 & 5,55 \\
\hline & $\mathrm{S}$ & 6,46 & 3,46 & 10,62 & 8,73 & 1,87 & 6,68 & 5,88 & 0,77 & 1,99 & 5,24 & 0,82 \\
\hline & Min. & 187 & 93 & 233 & 65 & 18,1 & 30 & 28 & 3,6 & 5,3 & 34,5 & 4,26 \\
\hline & Maks. & 207,5 & 105 & 271 & 96 & 23,5 & 56 & 54 & 6,5 & 10,6 & 52,1 & 6,91 \\
\hline \multirow{4}{*}{$\begin{array}{c}\text { II } \\
17 \mathrm{~m} .\end{array}$} & $\overline{\mathrm{x}}$ & 195,82 & 100,73 & 254,45 & 81,77 & 21,32 & 39,36 & 34,36 & 5,59 & 8,30 & 43,65 & 5,36 \\
\hline & $\mathrm{S}$ & 7,13 & 2,80 & 11,64 & 6,85 & 1,20 & 8,27 & 7,79 & 0,44 & 1,51 & 4,62 & 0,79 \\
\hline & Min. & 186,5 & 94,5 & 240 & 73,5 & 19 & 28 & 28 & 4,5 & 6,1 & 36,1 & 4,45 \\
\hline & Maks. & 207,5 & 104 & 273 & 96 & 23,08 & 56 & 56 & 6,2 & 10,6 & 52,1 & 6,58 \\
\hline \multirow{4}{*}{$\begin{array}{c}\text { III } \\
18 \mathrm{~m} .\end{array}$} & $\overline{\mathrm{x}}$ & 197,17 & 102,25 & 256,83 & 86,50 & 22,19 & 43,33 & 38,25 & 5,71 & 9,24 & 48,23 & 5,34 \\
\hline & $\mathrm{S}$ & 6,18 & 2,01 & 9,81 & 9,00 & 1,78 & 5,80 & 5,79 & 0,49 & 2,14 & 5,74 & 0,87 \\
\hline & Min. & 190 & 98 & 244 & 74 & 19,3 & 32 & 30 & 4,6 & 6,01 & 33,9 & 4,57 \\
\hline & Maks. & 209 & 106 & 275 & 106,5 & 25 & 50 & 48 & 6,4 & 13,3 & 60,9 & 6,93 \\
\hline \multirow{4}{*}{$\begin{array}{c}\text { IV } \\
19 \mathrm{~m} .\end{array}$} & $\overline{\mathrm{X}}$ & 197,29 & 102,46 & 257,33 & 90,88 & 23,44 & 52,92 & 50,75 & 5,76 & 9,56 & 49,43 & 5,26 \\
\hline & $\mathrm{S}$ & 7,03 & 3,40 & 9,05 & 7,21 & 1,58 & 7,69 & 3,93 & 0,43 & 1,86 & 7,31 & 0,84 \\
\hline & Min. & 190 & 91,5 & 245 & 80,5 & 21,1 & 46 & 42 & 5 & 7,4 & 31,4 & 4,01 \\
\hline & Maks. & 210 & 104,5 & 276 & 104,5 & 26,2 & 70 & 55 & 6,4 & 13,1 & 60,1 & 6,76 \\
\hline
\end{tabular}

2 lentelè. Tirtų Lietuvos krepšininkų fizinio išsivystymo atskirų tyrimų patikimumo rodikliai

\begin{tabular}{|c|c|c|c|c|c|c|c|c|c|c|c|c|}
\hline \multirow{2}{*}{ Tyrimai } & \multirow{2}{*}{ Patikimumas } & \multirow{2}{*}{ 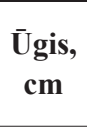 } & \multirow{2}{*}{$\begin{array}{c}\text { Ūgis } \\
\text { sèdint, } \\
\text { cm }\end{array}$} & \multirow{2}{*}{\begin{tabular}{|c|} 
Siek. \\
stovint, \\
$\mathrm{cm}$ \\
\end{tabular}} & \multirow{2}{*}{$\begin{array}{c}\text { Kūno } \\
\text { masé, } \\
\text { kg }\end{array}$} & \multirow{2}{*}{$\begin{array}{c}\mathrm{KMI} \\
\mathbf{k g} / \mathbf{m}^{2}\end{array}$} & \multicolumn{2}{|c|}{ Jèga, kg } & \multirow{2}{*}{$\begin{array}{c}\text { GPT, } \\
\text { I }\end{array}$} & \multirow{2}{*}{$\begin{array}{c}\text { Rieb., } \\
\quad 1\end{array}$} & \multirow{2}{*}{$\begin{array}{c}\text { Raum., } \\
\text { kg }\end{array}$} & \multirow{2}{*}{ RRMI } \\
\hline & & & & & & & D & $\mathbf{K}$ & & & & \\
\hline \multirow{2}{*}{ I-II } & $\mathrm{F}$ & 0,32 & 1,33 & 0,58 & 0,37 & 0,01 & 0,06 & 0,24 & 0,46 & 0,01 & 0,40 & 0,07 \\
\hline & $\mathrm{P}$ & 0,58 & 0,26 & 0,45 & 0,55 & 0,93 & 0,80 & 0,63 & 0,50 & 0,97 & 0,53 & 0,79 \\
\hline \multirow{2}{*}{$\mathrm{I}-\mathrm{III}$} & $\mathrm{F}$ & 1,28 & 6,92 & 1,99 & 1,98 & 1,49 & 1,47 & 0,99 & 0,91 & 1,25 & 6,63 & 0,04 \\
\hline & $\mathrm{P}$ & 0,27 & $\mathbf{0 , 0 1}$ & 0,18 & 0,17 & 0,24 & 0,24 & 0,33 & 0,35 & 0,29 & $\mathbf{0 , 0 2}$ & 0,84 \\
\hline \multirow{2}{*}{$\mathrm{I}-\mathrm{IV}$} & $\mathrm{F}$ & 1,21 & 0,79 & 1,16 & 11,18 & 9,18 & 17,82 & 12,30 & 1,85 & 2,56 & 7,09 & 0,001 \\
\hline & $\mathrm{P}$ & 0,28 & 0,38 & 0,29 & 0,004 & $\mathbf{0 , 0 1}$ & 0,001 & 0,001 & 0,19 & 0,12 & 0,01 & 0,97 \\
\hline \multirow{2}{*}{ II-III } & $\mathrm{F}$ & 0,24 & 2,28 & 0,28 & 1,98 & & 1,79 & 1,87 & 0,36 & 1,46 & 4,38 & 0,03 \\
\hline & $\mathrm{P}$ & 0,63 & 0,15 & 0,6 & 0,17 & 0,19 & 0,19 & 0,18 & 0,55 & 0,24 & $\mathbf{0 , 0 4}$ & 0,95 \\
\hline \multirow{2}{*}{$\mathrm{II}-\mathrm{IV}$} & $\mathrm{F}$ & 0,25 & 0,04 & 0,05 & 9,59 & 12,88 & 16,57 & 17,80 & 0,85 & 3,13 & 5,04 & 0,09 \\
\hline & $\mathrm{P}$ & 0,62 & 0,82 & 0,82 & 0,005 & 0,001 & 0,001 & 0,001 & 0,37 & 0,09 & $\mathbf{0 , 0 3}$ & 0,76 \\
\hline \multirow{2}{*}{ III-IV } & $\mathrm{F}$ & 0,02 & 2,47 & 0,11 & 1,72 & 3,31 & 11,87 & 13,8 & 0,08 & 0,15 & 0,20 & 0,06 \\
\hline & $\mathrm{P}$ & 0,96 & 0,13 & 0,75 & 0,2 & 0,08 & 0,002 & 0,001 & 0,79 & 0,17 & 0,66 & 0,81 \\
\hline
\end{tabular}

rodikliai smarkiai skiriasi nuo nesportuojančiujų. Nustatyta, kad tirtu jaunučiu (16 m.) vidutinis kūno masès rodiklis siekia 77,58 $\pm 8,73 \mathrm{~kg}$ ir vidutiniškai yra $10 \mathrm{~kg}$ didesnis $(\mathrm{p}<0,005)$ už nesportuojančiu to paties amžiaus Lietuvos ir JAV jaunuoliu rodiklius (Strong et al., 2005) (1 pav.). Tyrimo laikotarpiu krepšininkų kūno masé padidejo $-\overline{\mathrm{x}}=13,3 \mathrm{~kg}(\mathrm{p}<0,004)$.

Kūno masès indeksas (KMI), kaip ir kūno masè, kiekvienais metais didejo, tačiau tempai nebuvo vienodi. Tai susiję ir su ūgio, ir su kūno masès rodiklių kaita. Per pirmą tyrimų etapą KMI vidutinès didejjimo tendencijos siekè tik 0,43 , o per visą tyrimą $-2,59$ vienetu $(\mathrm{p}<0,01)$.

Fiziometrinius fizinio išsivystymo rodiklius gali paveikti fizinès pratybos (Trost et al., 2002;
Thompson et al., 2003; Marshall et al., 2004). Tirti krepšininkai reguliariai sportavo 8 kartus per savaitę. Ar tai lèmé raumenų statinès jègos padidejjimą, iš dalies galejo atsakyti atliktas tyrimas. Jau tyrimo pradžioje $16 \mathrm{~m}$. krepšininkų rodikliai buvo mažesni už to paties amžiaus nesportuojančiujų (2 pav.). 16 m. krepšininkų tiek dešinès, tiek kairès plaštakos vidutinè jèga per metus ne tik nepadidejo, bet netgi turejjo tendenciją mažèti. Kai tuo tarpu Lietuvos nesportuojančių to paties amžiaus moksleiviu plaštaku jëgos rodikliai šiek tiek didèjo. Nuo $18 \mathrm{~m}$. amžiaus užfiksuotas didžiausias krepšininkų jẻgos rodiklių padidejimas. Per vienerius metus dešinès plaštakos jèga vidutiniškai didèjo 9,59 $(\mathrm{p}<0,002) \mathrm{kg}$, kairès - net $12,5 \mathrm{~kg}$ $(\mathrm{p}<0,001)$. 

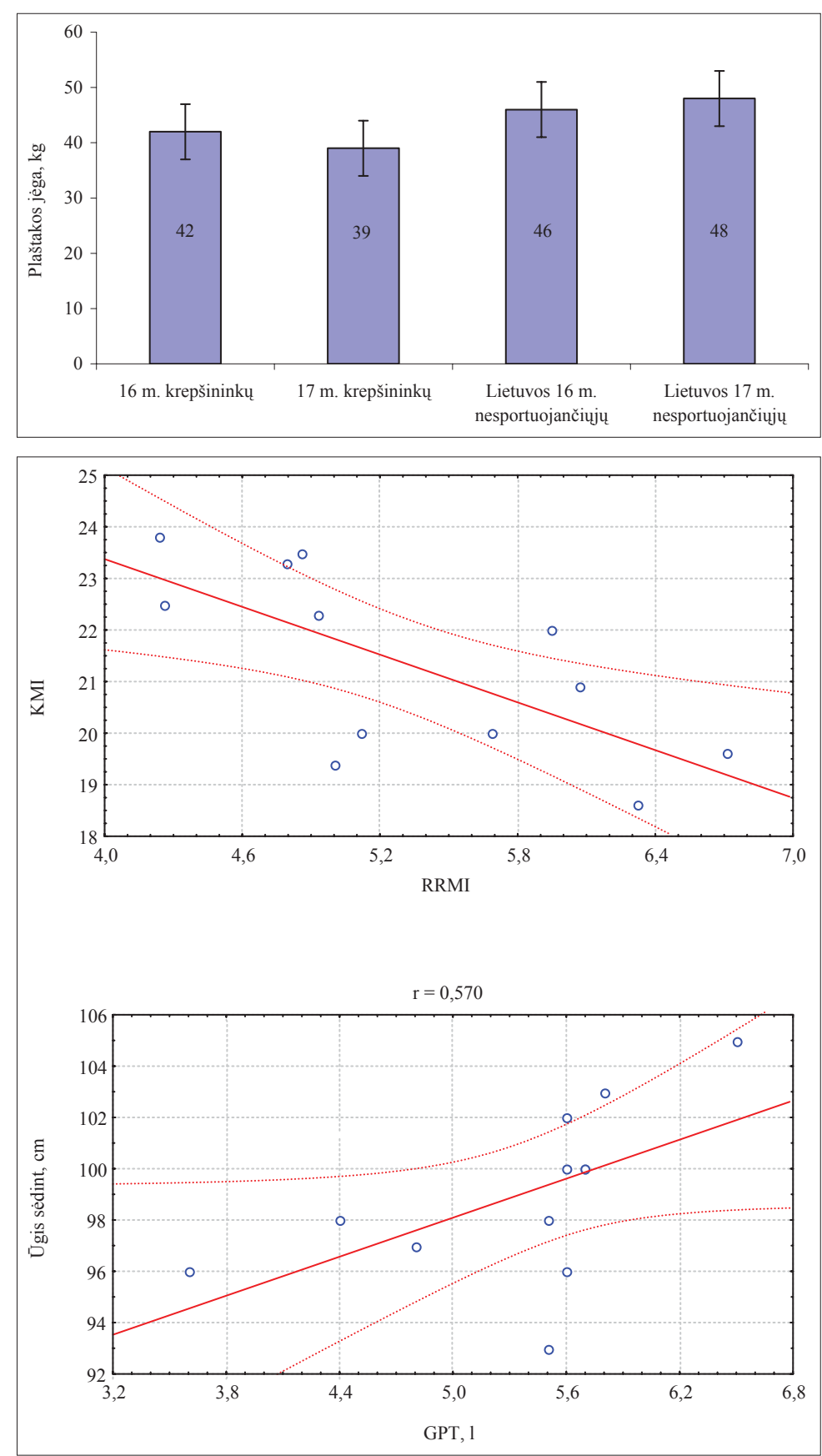

Ne tik augimo tempai, bet ir fiziniai pratimai skatina gyvybinio plaučių tūrio (GPT) didejimą (Johnson, Nelson, 1986). Tai leidžia vertinti ir kvejpavimo sistemos funkcini pajègumą. Tirtų krepšininkų GPT rodikliai per ketverius metus kito nedaug. Tyrimo pabaigoje vidutinis rodiklis siekè 5,76 $\pm 0,431$.

Akivaizdu, kad didèjant ūgiui ir kūno masei riebalų raumenų masè taip pat padidejo. Tiriamųjų augimo tempai nebuvo vienodi. Riebalu masè labiausiai padidejo, kai tiriamieji buvo 17 ir 18 metu amžiaus $-\overline{\mathrm{x}}=0,94 \mathrm{~kg}(\mathrm{p}>0,24)$, o per visą tyrimo laikotarpi $-\overline{\mathrm{x}}=1,9 \mathrm{~kg}(\mathrm{p}>0,12)$.

Tyrimo metu užfiksuotas ryškus raumenų masès padidejimas. Per ketverius metus šis rodiklis vidutiniškai padidejjo $8,24 \mathrm{~kg}(\mathrm{p}<0,01)$ ir siekè
2 pav. Tirtų Lietuvos krepšininkų ir nesportuojančiųjų plaštakų statinès jègos rodiklių palyginimas

3 pav. Tirtu Lietuvos krepšininku KMI ir RRMI $(r=-0,692)$, GPT ir ūgio sédint $(r=0,570)$ vidutiniu rodiklių koreliaciniai ryšiai
$49,43 \pm 7,31 \mathrm{~kg}$, o didžiausias raumenų masės prieaugis užfiksuotas laikotarpiu tarp antro ir trečio tyrimo $\overline{\mathrm{x}}=4,8 \mathrm{~kg}(\mathrm{p}<0,04)$.

Riebalų ir raumenų masès indeksas (RRMI) per ketverius metus nepakito. $16 \mathrm{~m}$. krepšininku rodiklis vidutiniškai siekė $5,55 \pm 0,82$ vienetų.

\section{REZULTATUQ APTARIMAS}

Ūgio kaitai fizinis aktyvumas didesnio poveikio neturi, tačiau atliktas tyrimas parode, $\mathrm{kad}$ i ívairaus amžiaus Lietuvos jaunimo rinktines patenka jaunuoliai, aukštesni už nesportuojančiuosius. Palyginus tirtų krepšininkų, JAV ir Lietuvos to paties amžiaus moksleiviu rodiklius matyti, 
kad nors nesportuojančiujų ūgis yra mažesnis, tačiau nuo 16 iki 18 metu augimo tempai visu yra panašūs. Tirtų Lietuvos devyniolikamečių rinktinè drauge su JAV bendraamžiais varžèsi pasaulio čempionate. Amerikiečiu komandos žaidejjų vidutinis ūgio rodiklis siekè 194,6 cm — vidutiniškai $2,7 \mathrm{~cm}$ jie buvo mažesni už tirtus lietuvius. Nors Lietuvos rinktinès žaideju vidutinis ūgio rodiklis buvo didesnis, pasiekti rezultatai blogesni už JAV. Tai rodo, kad ūgis yra privalumas tik pasiekus gera fizini ir technini parengtumo lygi.

Akivaizdu, kad tarp ūgio ir kūno masès yra koreliacinis ryšys $(r=0,583)$. Visgi daugelis autoriu teigia, kad fizinès pratybos didina raumenu masę, bet mažina riebalus (Malina, 1997; Trost et al., 2002; Marshall et al., 2004). Šio tyrimo metu nustatyta, kad krepšininkų kūno masė didesnè už nesportuojančiujų, o riebalų ir raumenu masès santykis - optimalus. Ištyrus statistinę duomenu priklausomybę matyti, kad kūno masès indeksas turi atvirkštini ryši su riebalų ir raumenų masès indeksu. Taigi kuo didesnis RRMI rodiklis, tuo mažesnis KMI (3 pav.). Taip pat egzistuoja gyvybinio plaučių tūrio ir ūgio sèdint rodiklių tarpusavio ryšys $(r=0,570)$.

Per ketverius metus raumenu mase ir jèga didèjo skirtingais tempais. Didžiausias raumenu masès prieaugis užfiksuotas per antrą tyrimų etapa, o plaštakų statinè jèga labiausiai didejjo per trečią. Tai rodo, kad hipertrofinès raumenų savybès buvo išugdytos anksčiau, o funkcinès galios padidèjo po metų. Jaunujų krepšininkų, kitų autorių atlikti to paties amžiaus irkluotojų ir dviratininkų fizinio išsivystymo tyrimai parodè (Dadelienè, Milašius, 2004) labai dideli $(r=0,986)$ kūno ir raumenų masès rodiklių koreliacini ryšic.

Atlikti tyrimai leido įvertinti specifinès grupès jaunuoliu, geriausių 16-19 m. krepšininkų, kurie atstovavo Lietuvai Europos ir pasaulio čempionatuose, fizinio išsivystymo ypatumus bei jų kaitą dèl fizinio krūvio ir augimo poveikio.

\section{IŠVADOS}

1. Lietuvos $16 \mathrm{~m}$. krepšinio rinktinès žaidèjų ūgis vidutiniškai $15,5 \mathrm{~cm}$ didesnis už nesportuojančių bendraamžių. Tačiau jų augimo tempai nuo 16 iki 18 metu yra beveik vienodi. Tai rodo, kad atranka į šią sporto šaką yra specifinè.

2. Tirtu jaunujų krepšininkų kūno masė vidutiniškai 10 kg didesnè už nesportuojančiujų, tačiau augimo tempai panašūs.

3. Atlikti tyrimai leidžia manyti, kad krepšinį žaidžiančiu jaunuolių plaštakų statinès jẻgos rodikliai yra nepakankami. Palyginus 16 ir $17 \mathrm{~m}$. žaidejų ir to paties amžiaus nesportuojančiuju rodiklius matyti, kad krepšininkų vidutiniai rodikliai blogesni.

4. Raumenu mase sparčiai augo nuo 17 metų, o raumenų statinè jèga smarkiai didejjo nuo 18-os. Manytume, kad tam turejo įtakos ir fizinis krūvis, ir fiziologiniai augimo dèsningumai.

\section{LITERATŪRA}

Dadelienė, R., Milašius, K. (2004). Body adaptation peculiarities in 15-17-year old junior training for cycling and rowing sports. Acta medica Lituanica, 11, 3, 41-49.

Eisenmann, J. C., Katzmarzyk, P. T., Perusse, L. et al. (2005). Aerobic fitness, body mass index, and CVD risk factors among adolescents: The Quebec family study. International Journal of Obesity, 29, 1077-1083.

EUROFITAS. (2002). Fizinio pajègumo testai, metodika. Parengè V. Volbekienè ir S. Kavaliauskas. Lietuvos moksleiviu fizinio pajégumo rezultatai. Vilnius.

Janz, K. F., Dawson, J. D., Mahoney, L. T. (2000). Tracking physical fitness and physical activity from childhood to adolescence: The Muscatine study. Medicine and Science in Sports and Exercise, 7 (32), 1250-1257.

Johnson, B. L., Nelson, J. K. (1986). Practical Measurements for Evaluation in Physical Education. United States of America. P. 126-127.

Juocevičius, A., Guobys, H. (1985). Reumatinemis ligomis sergančiuju fizinio pajègumo ir reabilitacijos potencialo kompleksinis ivertinimas. Vilnius.

Katzmarzyk, P. T., Tremblay, A., Perusse, L., Despres, J. P.
(2003). The utility of the international child and adolescent overweight guidelines for predicting coronary heart disease risk factors. Journal of Clinical Epidemiology, 5 (56), 456-462.

Lašienė, D., Pavilonis, S., Tutkuvienè, J. (1994). Lytinis brendimas ir jo juvertinimas: mokymo metodinès rekomendacijos. Kaunas. P. 4-23.

Malina, R. M., Bouchard, C. (1991). Growth, Maturation, and Physical Activity. Champaign, Illinois: Human Kinetics.

Malina, R. M. (1997). Prospective and retrospective longitudinal studies of the growth, maturation and fitness of Polish youth active in sport. International Journal of Sports Medicine (Themie), 1, 179-185.

Marshall, S. J., Biddle, S. J. H., Gorely, T., Cameron, N., Murdey, I. (2004). Relationships between media use, body fatness and physical activity in children and youth: A meta-analysis. International Journal of Obesity, 28, 1238-1246.

Matton, L., Duvigneaud, N., Wijndaele, K. et al. (2007). Secular trends in anthropometric characteristics, physical 
fitness, physical actiavity, and biological maturation in Flemish adolescents between 1969 and 2005. American Journal of Human Biology, 3 (19), 345-357.

Paulauskas, R., Paulauskienè, R., Levinsonienè, A. (2005). Lietuvos jaunučių krepšinio rinktinès rengimas Europos čempionatui ir adaptacijos prie fizinių krūvių ypatumai. Sporto mokslas, 2 (40), 67-71.

Skernevičius, J., Raslanas, A., Dadelienè, R. (2004). Sporto mokslo tyrimu metodologija. Vilnius: Lietuvos sporto informacijos centras.
Strong, W., Malina, R., Blimkie, C. et al. (2005). Evidence based physical activity for school-age youth. The Journal of Pediatrics, 6 (146), 732-737.

Thompson, A. M., Baxter, J., Mirwald, R., Bailey, D. (2003). Comparison of physical activity in male and female children: Does maturation matter? Medicine and Science in Sports and Exercise, 10 (35), 1684-1690.

Trost, S., Pate, R. R., Sallis, J. F., Freedson, P. S., Wendel, C. (2002). Age and gender differences in objectively measured physical activity in youth. Medicine and Science in Sports and Exercise, 2 (34), 350-35.

\title{
PHYSICAL DEVELOPMENT OF THE LITHUANIAN NATIONAL TEAM YOUNG BASKETBALL PLAYERS, ITS PECULIARITIES AND DEVELOPMENT
}

\author{
Rūtenis Paulauskas \\ Vilnius Pedagogical University, Vilnius, Lithuania
}

\begin{abstract}
The preparation of young basketball players is a well-organised pedagogical process in Lithuania. Basketball schools educate boys and girls from 7 to 18 years, organize competitions for different age groups, train players for the national teams. Annually growing competition between young basketball players necessitates not only to care about the tactical and technical qualities but also to improve their physical abilities and to evaluate their level.

The research question of this study was: how regular training affects physical development indices in the period of four years.

The aim of the current study was to investigate the physical development of the best young (16-19 year old) basketball players and to compare it with their not exercising contemporaries.

We studied the candidates of various age $(n=14)$ to the Lithuanian junior national team. Our examination was held for four subsequent years - from 16 to 19 years old. The studies were carried out every summer during the preparation for the European and world championships. We investigated the: 1) standing height, sitting height, standing long reach; 2) body mass, body mass index; 3) dynamometry; 4) vital volume of lungs; 5) muscle and fat mass proportions.

The data were processed applying methods of mathematic statistics. We estimated that standing height of 16 year old basketball players was significantly bigger than of not exercising youngsters. The average difference in results was $15.5 \mathrm{~cm}$. However, the increase rate at this age was the same. It shows that the selection of persons for the basketball practice is specific.

The body mass of the basketball players was $10 \mathrm{~kg}$ bigger on average than of not exercising contemporaries, but their growth rate was the similar.

Our examination showed that dynamometrical indices of active basketball players were not sufficient. The comparison of the static muscle power of basketball players with not exercising youngsters showed worse results. We estimated that the biggest growth of muscle mass and power was found at the age of 18 years and more. It was associated with their physical activity and the rate of maturation.
\end{abstract}

Keywords: physical activity, height, body mass, power, fat mass.

Gauta 2007 m. spalio 24 d.

Received on October 24, 2007

Priimta $2008 \mathrm{~m}$. vasario $20 \mathrm{~d}$.

Accepted on February 20, 2008
Rūtenis Paulauskas

Vilniaus pedagoginis universitetas

(Vilnius Pedagogical University)

Studentu g. 39, LT-06316 Vilnius

Lietuva (Lithuania)

Tel +37069839079

E-mail rutenis2006@yahoo.com 